\title{
Calibration and validation of an activated sludge model for a pilot-scale anoxic/anaerobic/aerobic/post-anoxic process
}

\author{
Xiang HU, Li XIE ${ }^{\dagger+}$, Chuang MI, Dian-hai YANG \\ (State Key Laboratory of Pollution Control and Resources Reuse, Tongji University, Shanghai 200092, China) \\ †E-mail: sally_xieli@163.com
}

Received Mar. 6, 2014; Revision accepted July 9, 2014; Crosschecked Aug. 22, 2014

\begin{abstract}
The aim of this study was to establish an activated sludge model and to verify its predictability for use in a pilot-scale anoxic/anaerobic/aerobic/post-anoxic (modified AAO) process. Respirometric measurements were conducted to identify the influent organic characteristics and to determine the yield coefficient $\left(Y_{\mathrm{H}}\right)$ and decay coefficient $\left(b_{\mathrm{H}}\right)$ for heterotrophic biomass (OHOs). The values obtained for $Y_{\mathrm{H}}$ and $b_{\mathrm{H}}$ were $0.72 \mathrm{mg} \mathrm{COD} / \mathrm{mg}$ COD and $0.275 \mathrm{~d}^{-1}$, respectively. Within the model's calibration, the most influential stoichiometric and kinetic parameters were identified with the aid of sensitivity analysis. The output of the model was most sensitive to parameters associated with the growth and decay of OHOs and ammonia-oxidizing biomass (AOB) $\left(Y_{\mathrm{H}}, \mu_{\mathrm{maxH}}, K_{\mathrm{s}}, b_{\mathrm{H}}, \mu_{\mathrm{maxA}}, K_{\mathrm{NH} 4 \mathrm{~A}}\right.$, and $\left.b_{\text {aeroa, }}\right)$. Furthermore, all the calibrated parameters, with the exception of $Y_{\mathrm{PAO} \text {, aerob }}$ related to the phosphorus accumulating organisms (PAOs), could be regarded as influential. Both steady-state and dynamic simulations indicated good agreement between the simulated and measured values of the output variables. The calibrated model can be used to provide insight into the pilot-scale modified AAO process, and information needed to optimize design and operation when applied at full-scale.
\end{abstract}

Key words: Activated sludge model, Simulation, Calibration, Validation, Sensitivity analysis doi: 10.1631 jzus.A14b0066

Document code: A

CLC number: O242.1

\section{Introduction}

Increasingly stringent limits for nitrogen and phosphorus contamination have encouraged the widespread use of various biological nutrient removal (BNR) processes in wastewater treatment practice worldwide, both for upgrading existing wastewater treatment facilities and for the design of new facilities (Hu et al., 2012). Facing diverse organisms and complicated conversion processes in a BNR system, activated sludge mathematical models have proved powerful and valuable tools (Petersen et al., 2002; 2003). In recent years, many mathematical models

\footnotetext{
$\ddagger$ Corresponding author

* Project supported by the National Water Pollution Control and Management of Science and Technology (No. 2011ZX07303-001), China (C) Zhejiang University and Springer-Verlag Berlin Heidelberg 2014
}

based on the activated sludge model (ASM) family (ASM1, ASM2, ASM2d, and ASM3) have been evaluated and optimized for BNR processes such as anaerobic/anoxic/aerobic (AAO) (Pai, 2007; Liwarska-Bizukojc et al., 2011), Johannesburg (JHB) (Makinia et al., 2006), modified University of Cape Town (MUCT) (Czerwionka et al., 2012), sequencing batch reactor (SBR) (Ni et al., 2009), and membrane bioreactor (MBR) (Fenu et al., 2010). A novel anoxic/ anaerobic/aerobic (modified AAO) process with an anoxic stage before an anaerobic stage, developed by Zhang and Gao (2000), has shown high removal efficiencies for nitrogen and phosphorus from low $\mathrm{C} / \mathrm{N}$ wastewater. This modified AAO process has been extensively applied in more than 100 wastewater treatment plants (WWTP) in China and Japan (Fu et al., 2004). Nevertheless, limited information is available on performance evaluation and especially 
on mathematical modeling of the modified AAO process, which requires detailed wastewater characterization and model calibration/validation (Gernaey et al., 2004).

Model calibration, which is necessary for successfully applying mathematical models to describe the overall behavior of a BNR system, is defined as the adaptation of the model to fit a certain set of information obtained from a practical WWTP (Petersen et al., 2002). Different methods for the calibration of ASM models have been developed (Vanrolleghem et al., 2003; Langergraber et al., 2004), and a detailed summary and comparisons were presented by Sin et al. (2005). Note that the above studies emphasized the role of sensitivity analysis in the process of model calibration. The calibration and determination of all model parameters is expensive and time-consuming. Thus, a sensitivity analysis that enables the identification of the most influential parameters would be a very practical tool for a given model. Hence, a sensitivity analysis could be incorporated into the calibration protocol, both to minimize effort and to optimize the overall calibration procedure (Vanrolleghem et al., 2003). Several attempts have been made to identify the most sensitive parameters for ASM-family models (Weijers and Vanrolleghem, 1997; Brun et al., 2002; Petersen et al., 2002; Makinia et al., 2006). Weijers and Vanrolleghem (1997) proposed a reduced set of the most sensitive parameters by means of sensitivity analysis, for calibrating ASM1 to a full-scale plant. The reduced set included the following kinetic and stoichiometric parameters: a yield coefficient for heterotrophic biomass $\left(Y_{\mathrm{H}}\right)$, a yield coefficient for autotrophic biomass $\left(Y_{\mathrm{A}}\right)$, the maximum specific growth rate for heterotrophic biomass $\left(\mu_{\operatorname{maxH}}\right)$, a decay rate constant for heterotrophic biomass $\left(b_{\mathrm{H}}\right)$, the maximum specific growth rate for autotrophic biomass $\left(\mu_{\max \mathrm{A}}\right)$, a substrate halfsaturation constant for heterotrophic organisms $\left(K_{\mathrm{s}}\right)$, an oxygen half-saturation constant for autotrophic organisms $\left(K_{\mathrm{OA}}\right)$, and an anoxic growth factor $\left(\eta_{\text {anoxic,H}}\right)$. Makinia et al. (2006) identified the most influential parameters for ASM2d and ASM3P models for simulation of nitrogen removal on the basis of the normalized sensitivity coefficient $\left(S_{i, j}\right)$. The most influential parameters for effluent $\mathrm{PO}_{4}{ }^{3-}-\mathrm{P}$ and $\mathrm{NH}_{4}{ }^{+}-\mathrm{N}$ concentrations were related to the ammoniaoxidizing biomass (AOB), phosphorus accumulating organisms (PAOs) and wastewater composition. However, low values of $S_{i, j}$ were associated with effluent $\mathrm{NO}_{3}{ }^{-}-\mathrm{N}$. Liwarska-Bizukojc et al. (2011) reported that, based on calculations of $S_{i, j}, 17$ (steady-state) or 19 (dynamic conditions) kinetic and stoichiometric parameters were sensitive. Most of them were associated with growth and decay of ordinary heterotrophic organisms (OHOs) and PAOs.

The aim of this study was to establish and verify the predictability of an activated sludge model for a pilot-scale anoxic/anaerobic/aerobic/post-anoxic (modified AAO) process. Calibration and validation of the model were implemented, with the most sensitive parameters singled out by sensitivity analysis. The use of sensitivity analysis in the development of an activated sludge model for a modified AAO process has not previously been reported.

\section{Materials and methods}

\subsection{Pilot-scale modified AAO plant}

The pilot-scale modified AAO plant treats municipal wastewater at a flow rate of $50 \mathrm{~m}^{3} / \mathrm{d}$, and is located in the city of Hefei, Anhui Province (southern China). The process configuration is anoxic/ anaerobic/aerobic/post-anoxic followed by a membrane tank to replace the settling tank for solid-liquid separation (Fig. 1). A unique feature of this system is a post-anoxic zone, located between the aerobic zone and the membrane tank to reduce the dissolved oxygen (DO) concentration of the aerobic effluent to below $0.5 \mathrm{mg} / \mathrm{L}$ before its recirculation to the anoxic zone. Two different internal recycles were provided: R1 $(Q=400 \%)$ from the post-anoxic to the anoxic zone, and R2 ( $Q=100 \%)$ from the membrane tank to the aerobic zone. The anoxic and anaerobic zones were each equipped with a low-speed mixer to keep the mixed liquor suspended solids (MLSS) in suspension. The membrane tank was fitted with a submerged hollow fiber membrane (PVDF) with a nominal pore size of $0.1 \mu \mathrm{m}$ (Mohua Membrane Materials of Science and Technology Co., Ltd., Suzhou, China). The total membrane area was $256 \mathrm{~m}^{2}$. A permeate pump was operated according to a timing sequence that consisted of a 9 min switch on and a 1 min switch off. Excess sludge was removed daily as waste from the membrane tank to maintain a 
relatively stable MLSS concentration and the desired sludge retention time (SRT) of $16 \mathrm{~d}$. The plant was provided with a programmable logic controller (PLC) that controlled all of the automatic control loops of the system. The detailed design and operational parameters of the modified AAO plant are summarized in Table 1.

\subsection{Data collection for the calibration and valida- tion of the model}

Data collected from the pilot-scale modified AAO plant from April to May 2012 (Phase I) were used as input values for model calibration. The model was then validated on the basis of two independent datasets, obtained in June (Phase II) and July 2012 (Phase III) (Table 2), respectively. These data were evaluated using Student's $t$-test (to compare the means of the different datasets) and the $F$-test (to compare differences between the standard deviations of the datasets). Student's $t$-test was paired with the $F$-test to determine the statistical significance of the observed differences between the measured data for the total chemical oxygen demand (TCOD), soluble COD (SCOD), ammonia $\left(\mathrm{NH}_{4}{ }^{+}-\mathrm{N}\right)$, nitrate $\left(\mathrm{NO}_{3}{ }^{-} \mathrm{N}\right)$, nitrite $\left(\mathrm{NO}_{2}{ }^{-}-\mathrm{N}\right)$, total nitrogen (TN), total phosphorus (TP), total suspended solids (TSS), and $\mathrm{pH}$ at the $95 \%$ confidence level. Finally, the average values were used as input for the model. The analysis of TCOD, SCOD, $\mathrm{NH}_{4}{ }^{+}-\mathrm{N}, \mathrm{NO}_{3}{ }^{-}-\mathrm{N}, \mathrm{NO}_{2}{ }^{-}-\mathrm{N}, \mathrm{TN}, \mathrm{TP}$, and TSS was conducted in accordance with standard methods (APHA, 1998). The $\mathrm{pH}$ was measured using a Cyber Scan pH 510 pH/ORP pH meter (Eutech).

\subsection{Respirometric tests}

Respirometric tests, based on the measurement of oxygen uptake rate (OUR), were first used to estimate the COD fractions of the influent wastewater.
At the beginning of the respirometric test, fresh returned activated sludge (RAS) was diluted with the treated wastewater to obtain $3 \mathrm{~L}$ of mixed liquor with

Table 1 Design and operational parameters of the pilotscale modified AAO plant

\begin{tabular}{lc}
\hline \multicolumn{1}{c}{ Operating parameter } & Value \\
\hline Anoxic $(\mathrm{ANO})$ volume $\left(\mathrm{m}^{3}\right)$ & 12 \\
Anaerobic $(\mathrm{ANE})$ volume $\left(\mathrm{m}^{3}\right)$ & 6 \\
Aerobic volume $(\mathrm{AE})\left(\mathrm{m}^{3}\right)$ & 12 \\
Post-anoxic volume $(\mathrm{PANO})\left(\mathrm{m}^{3}\right)$ & 6 \\
MBR volume $\left(\mathrm{m}^{3}\right)$ & 12 \\
Influent flow $\left(\mathrm{m}^{3} / \mathrm{d}\right)$ & 50 \\
$\mathrm{R}^{\mathrm{a}}(\%)$ & 400 \\
$\mathrm{R} 2^{\mathrm{b}}(\%)$ & 100 \\
$\mathrm{HRT}(\mathrm{h})$ & 14.66 \\
$\mathrm{SRT}(\mathrm{d})$ & 16 \\
Temperature $\left({ }^{\circ} \mathrm{C}\right)$ & $25 \pm 7$ \\
$\mathrm{pH}$ & $7.5 \pm 0.5$ \\
$\mathrm{MLSS}$ in AE $(\mathrm{mg} / \mathrm{L})$ & $3500 \pm 1000$ \\
MLSS in $\mathrm{MBR}(\mathrm{mg} / \mathrm{L})$ & $5500 \pm 2500$ \\
DO in AE $(\mathrm{mg} / \mathrm{L})$ & $2.5 \pm 0.5$ \\
DO in MBR $(\mathrm{mg} / \mathrm{L})$ & $7.0 \pm 1.0$ \\
\hline
\end{tabular}

${ }^{a}$ Recycle ratio with respect to inflow flow from PANO to ANO;

${ }^{\mathrm{b}}$ Recycle ratio with respect to inflow flow from MBR to AE

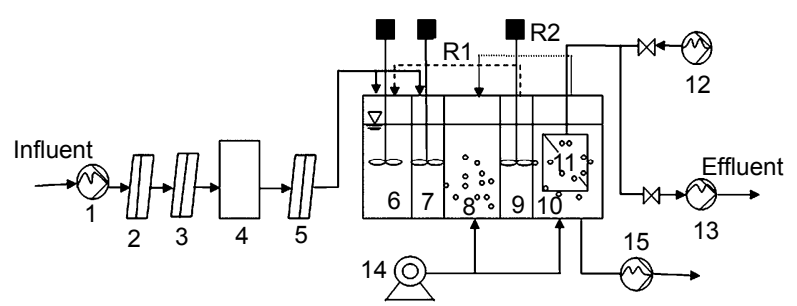

1: influent pump; 2: first screen; 3: second screen; 4: aerated grit chamber; 5: fine screen; 6: anoxic zone; 7: anaerobic zone; 8: aerobic zone; 9: post-anoxic zone; 10: membrane zone; 11: hollow-fiber membrane; 12: backwash pump; 13: permeate pump; 14: blower; 15: excess sludge pump

Fig. 1 Schematic diagram of the pilot-scale modified AAO plant

Table 2 Influent and effluent characteristics at different phases (unit: $\mathrm{mg} / \mathrm{L}$ except $\mathbf{~ p H}$ )

\begin{tabular}{ccccccccccc}
\hline Phase & TCOD & SCOD & $\mathrm{NH}_{4}{ }^{+}-\mathrm{N}$ & $\mathrm{NO}_{3}{ }^{-}-\mathrm{N}$ & $\mathrm{NO}_{2}{ }^{-} \mathrm{N}$ & $\mathrm{TN}$ & $\mathrm{TP}$ & $\mathrm{TSS}$ & $\mathrm{pH}$ \\
\hline \multirow{2}{*}{$\mathrm{I}^{\mathrm{a}}$} & Influent & $224 \pm 68$ & $97 \pm 24$ & $28.71 \pm 10.86$ & $1.06 \pm 0.95$ & $0.06 \pm 0.002$ & $50 \pm 3.12$ & $4.20 \pm 1.80$ & $127 \pm 11$ & $7.63 \pm 0.12$ \\
& Effluent & $22.47 \pm 1.47$ & - & $1.47 \pm 1.28$ & $25.08 \pm 2.14$ & $0.04 \pm 0.002$ & $27.05 \pm 2.50$ & $2.31 \pm 2.19$ & $0 \pm 0$ & $7.18 \pm 0.28$ \\
\hline \multirow{2}{*}{$\mathrm{II}^{\mathrm{b}}$} & Influent & $239 \pm 135$ & $102 \pm 29$ & $31.26 \pm 8.52$ & $1.04 \pm 0.39$ & $0.06 \pm 0.003$ & $40.44 \pm 8.69$ & $4.60 \pm 2.41$ & $116 \pm 23$ & $7.53 \pm 0.10$ \\
& Effluent & $21.59 \pm 3.54$ & - & $1.83 \pm 1.18$ & $23.02 \pm 2.79$ & $0.04 \pm 0.002$ & $25.36 \pm 2.86$ & $2.04 \pm 1.56$ & $0 \pm 0$ & $7.12 \pm 0.24$ \\
\hline \multirow{2}{*}{$\mathrm{III}^{\mathrm{c}}$} & Influent & $232 \pm 87$ & $91 \pm 31$ & $32.41 \pm 7.62$ & $0.94 \pm 0.38$ & $0.06 \pm 0.002$ & $40.29 \pm 8.30$ & $3.16 \pm 1.70$ & $133 \pm 26$ & $7.61 \pm 0.08$ \\
& Effluent & $20.89 \pm 2.93$ & - & $1.67 \pm 0.92$ & $20.93 \pm 3.27$ & $0.03 \pm 0.002$ & $22.34 \pm 3.93$ & $2.17 \pm 1.63$ & $0 \pm 0$ & $6.92 \pm 0.11$ \\
\hline
\end{tabular}

${ }^{\mathrm{a}} \mathrm{Mean} \pm \mathrm{SD}(n=26) ;{ }^{\mathrm{b}} \mathrm{Mean} \pm \mathrm{SD}(n=21) ;{ }^{\mathrm{c}} \operatorname{Mean} \pm \mathrm{SD}(n=19)$ 
an MLVSS concentration of around $1500 \mathrm{mg} / \mathrm{L}$. The actual MLVSS concentration in the reactor was measured at the beginning of the test. The DO set point in the main reactor was $6.0 \mathrm{mg} \mathrm{O} / \mathrm{L}$. The OUR measurement in one cycle was conducted for 3 min.

Respirometric tests were also carried out to measure the kinetic parameters of the heterotrophic biomass, i.e., the heterotrophic yield coefficient $\left(Y_{\mathrm{H}}\right)$ and decay coefficient $\left(b_{\mathrm{H}}\right)$. Detailed methods for evaluation of $Y_{\mathrm{H}}$ and $b_{\mathrm{H}}$ can be found in (Ni and $\mathrm{Yu}$, 2008).

\subsection{Model and simulation environment}

The simulations in this work were performed using the full general activated sludge (AS) model implemented in BioWin ${ }^{\mathrm{TM}} 3.1$ (EnvirnSim 2010). The modified AAO plant was modeled using the basic reactors available in BioWin $^{\mathrm{TM}}$ 3.1, i.e., influent, non-aerated bioreactors, aerated bioreactors, MBR, nitrate recirculation, effluent, and sludge wastage effluent (Fig. 2).

\subsection{Sensitivity analysis}

Sensitivity analysis was used to evaluate the extent to which the parameters used in model calibration could influence the model's output. The analysis was conducted using the various carbonaceous and nutrient fractions in the wastewater (estimated from measurements of the influent), as well as the default values for each stoichiometric and kinetic parameter defined in the BioWin AS model. Specifically, the sensitivity analysis used the normalized sensitivity functions $\left(S_{i, j}\right)$ shown in Eq. (1) defined by US EPA (2009), representing the percentage change in the output variable $\left(y_{j}\right)$, resulting from a $10 \%$ change in the input variable $\left(x_{i}\right)$ :

$$
S_{i, j}=\frac{\Delta y_{j} / y_{j}}{\Delta x_{i} / x_{i}} .
$$

The influence of each parameter on the model's output was classified into one of four categories proposed by Petersen et al. (2002): (a) no significant influence $\left(S_{i, j}<0.25\right)$; (b) influential $\left(0.25 \leq S_{i, j}<1\right)$; (c) very influential $\left(1 \leq S_{i, j}<2\right)$; (VI) extremely influential $\left(S_{i, j} \geq 2\right)$. When the values of a parameter and the output change were in the same direction, this was interpreted as positive; otherwise, the result was considered negative.

\section{Results}

\subsection{Respirometric tests results}

The composition of the influent COD was calculated based on respirometric profiles, and the contributions of the constituents to the TCOD are presented in Table 3 . The estimated readily biodegradable fraction $\left(S_{\mathrm{S}}\right)$ and the slowly biodegradable COD $\left(X_{\mathrm{S}}\right)$ accounted for $6.0 \%-11.2 \%$ and for $6.9 \%-16.8 \%$ of TCOD, respectively. Comparative studies performed on raw wastewater in a BNR plant in southern China revealed a similar ratio of $S_{\mathrm{S}}$ in the range of $6.9 \%-10.3 \%$, but higher $X_{\mathrm{S}}$ ratio $(38.9 \%-45.5 \%)$ of TCOD (Zhou et al., 2009). Higher ratios of $S_{\mathrm{S}}$ and $X_{\mathrm{S}}$ of TCOD were reported in another modified AAO plant in southern China (Zhou et al., 2011). The fraction of inert particulate organic compounds $\left(X_{\mathrm{I}}\right)$ in this study accounted for $60.6 \%-70.1 \%$ of TCOD, much higher than reported values $(18.5 \%-45.5 \%)$ for wastewaters in China (Zhou et al., 2009; 2011). The most likely reason for the relatively lower $S_{\mathrm{S}}$ and $X_{\mathrm{S}}$ but higher $X_{\mathrm{I}}$ in this study is that the influent was not raw wastewater, but wastewater from the primary

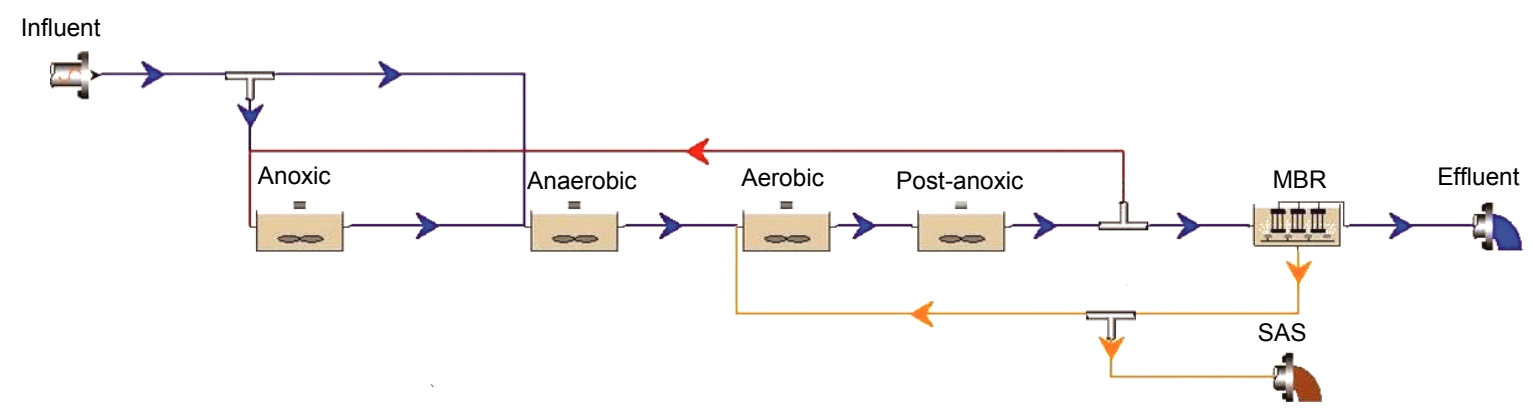

Fig. 2 Model configuration of the modified AAO plant in the BioWin simulator SAS: surplus activated sludge 
settled clarifier, in which $S_{\mathrm{S}}$ was biodegraded and $X_{\mathrm{S}}$ was partly hydrolyzed. Another possibility is that the biodegradable substrates in the influent partially converted to non-biodegradable organic compounds under the active biomass growth in the sewer after a long pipeline transportation.

Based on the respirometric results (Fig. 3), the $Y_{\mathrm{H}}$ and $b_{\mathrm{H}}$ for the heterotrophic biomass were calculated as $0.72 \mathrm{mg}$ COD/mg COD and $0.275 \mathrm{~d}^{-1}$, respectively. This will be discussed in detail in Section 3.4.

\subsection{Preliminary steady-state simulations}

It is clear from other studies that there is an interaction between wastewater characteristics and the calibration of a full-scale model to the available data (Petersen et al., 2002). In this study, the various carbonaceous and nutrient fractions present in the
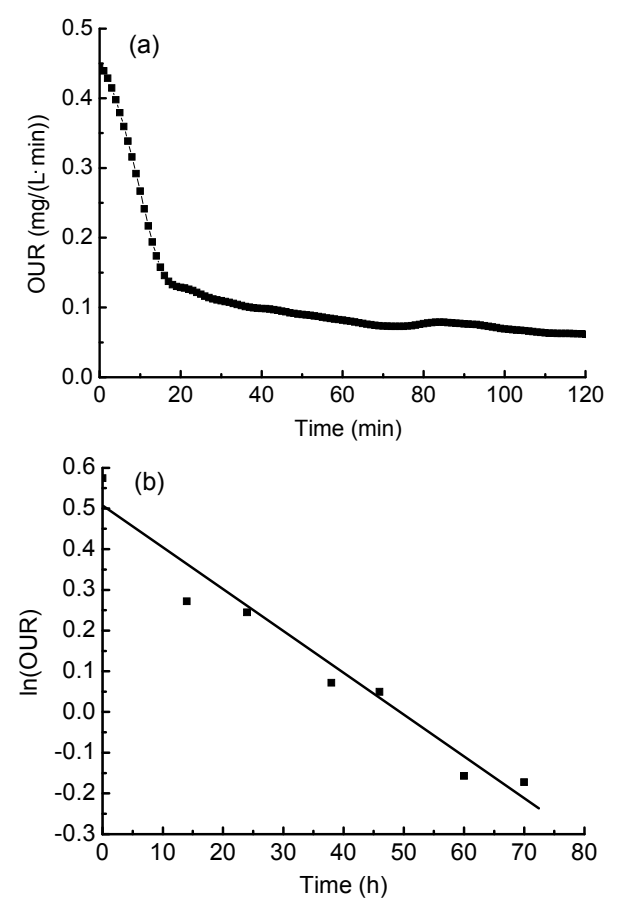

Fig. 3 Typical respirometric profiles used for the measurements of (a) $Y_{\mathrm{H}}$ and (b) $b_{\mathrm{H}}$ influent included in the BioWin AS model are listed in Table 4. If data were not available, the default values in the model were used.

The simulations, performed with the default values of the kinetic and stoichiometric parameters in the BioWin AS model, revealed discrepancies between the measured and simulated values of the output variables (Fig. 4). These discrepancies were especially prominent with several output variables characterizing the effluent, i.e., $\mathrm{COD}, \mathrm{TN}, \mathrm{NH}_{4}{ }^{+}-\mathrm{N}$, and $\mathrm{NO}_{3}{ }^{-}-\mathrm{N}$. This suggested the need for model calibration.

\subsection{Sensitivity analysis}

The normalized sensitivity coefficient $\left(S_{i, j}\right)$ ranks model parameters based on their contribution to the overall error in the model predictions. In this study,

Table 4 Default and calibrated carbonaceous and nutrient fractions in wastewater

\begin{tabular}{|c|c|c|}
\hline Fraction & $\begin{array}{c}\text { Default } \\
\text { value }\end{array}$ & $\begin{array}{l}\text { Input } \\
\text { value }\end{array}$ \\
\hline $\begin{array}{l}\text { Readily biodegradable, } \\
F_{\text {bs }}(\mathrm{g} \text { COD } / \mathrm{g} \text { TCOD })\end{array}$ & 0.20 & $0.22^{\mathrm{a}}$ \\
\hline Acetate, $F_{\text {ac }}(\mathrm{g} \mathrm{COD} / \mathrm{g}$ rbCOD $)$ & 0.15 & 0.15 \\
\hline $\begin{array}{l}\text { Non-colloidal slowly biodegradable, } \\
F_{\text {xsp }}(\mathrm{g} \text { COD/g sbCOD) }\end{array}$ & 0.75 & $0.54^{\mathrm{a}}$ \\
\hline $\begin{array}{l}\text { Non-biodegradable soluble, } \\
F_{\text {us }}(\text { g COD } / \text { g TCOD })\end{array}$ & 0.05 & $0.14^{\mathrm{a}}$ \\
\hline $\begin{array}{l}\text { Non-biodegradable particulate, } \\
F_{\text {up }}(\mathrm{g} \text { COD } / \mathrm{g} \text { TCOD })\end{array}$ & 0.13 & $0.10^{\mathrm{a}}$ \\
\hline Ammonia, $F_{\text {na }}\left(\mathrm{g} \mathrm{NH}_{3}-\mathrm{N} / \mathrm{g} \mathrm{TKN}\right)$ & 0.66 & $0.57^{\mathrm{a}}$ \\
\hline $\begin{array}{l}\text { Particulate organic nitrogen, } \\
F_{\text {nox }}(\text { g N/g Organic N) }\end{array}$ & 0.50 & $0.10^{\mathrm{a}}$ \\
\hline $\begin{array}{l}\text { Soluble non-biodegradable TKN, } \\
F_{\text {nus }}(\mathrm{g} \mathrm{N} / \mathrm{g} \mathrm{TKN})\end{array}$ & 0.02 & 0.02 \\
\hline $\begin{array}{l}\mathrm{N}: \mathrm{COD} \text { ratio for non-biodegradable } \\
\text { particulate COD, } F_{\mathrm{upN}}(\mathrm{g} \mathrm{N} / \mathrm{g} \mathrm{COD})\end{array}$ & 0.035 & $0.036^{\mathrm{a}}$ \\
\hline Phosphate, $F_{\mathrm{po} 4}\left(\mathrm{~g} \mathrm{PO}_{4}-\mathrm{P} / \mathrm{g}\right.$ TP $)$ & 0.50 & $0.62^{\mathrm{a}}$ \\
\hline $\begin{array}{l}\text { P:COD ratio for influent non- } \\
\text { biodegradable particulate COD, } \\
F_{\text {upP }}(\mathrm{g} \mathrm{P} / \mathrm{g} \text { COD })\end{array}$ & 0.011 & $0.015^{\mathrm{a}}$ \\
\hline
\end{tabular}

Table 3 Organic matter fraction in the influent at the modified AAO plant

\begin{tabular}{ccccc}
\hline \multirow{2}{*}{ Component } & $\begin{array}{c}\text { Concentration } \\
(\mathrm{mg} / \mathrm{L})\end{array}$ & This study & Plant 1 (Zhou et al., 2009) & Plant 2 (Zhou et al., 2011) \\
\cline { 3 - 5 } & $12.9-35.8$ & $8.2-22.0$ & $6.3-9.9$ & $10.65-17.1$ \\
$S_{\mathrm{I}}$ & $10.2-18.2$ & $6.0-11.2$ & $6.9-10.3$ & Approximately 20 \\
$S_{\mathrm{S}}$ & $98.7-129.4$ & $60.6-71.1$ & $23.3-31.1$ & $17.33-34.34$ \\
$X_{\mathrm{I}}$ & $12.8-31.2$ & $6.9-16.8$ & $38.9-45.5$ & $14.20-26.41$ \\
$X_{\mathrm{S}}$ & $156.2-185.8$ & 100.0 & 100.0 & 100.00 \\
TCOD & &
\end{tabular}


the sensitivity analysis comprised 11 stoichiometric and 24 kinetic parameters. The most sensitive $\left(S_{i, j} \geq 0.25\right)$ parameters and their corresponding $S_{i, j}$, calculated with respect to 8 effluent characteristics, are presented in Table 5. However, for two of them, i.e., effluent COD and $\mathrm{pH}$, the $S_{i, j}$ values were always below 0.25 . Note also that as all the $S_{i, j}$ values for the PAOs were below 0.25 , they were excluded from Table 5. Based on the values of $S_{i, j}$ for each parameter, 4 stoichiometric and 18 kinetic parameters were found to be sensitive while 9 parameters could be classified as influential $\left(0.25 \leq S_{i, j}<1\right), 6$ as very influential $\left(1 \leq S_{i, j}<2\right)$, and 7 as extremely influential $\left(S_{i, j} \geq 2\right)$.

Among the 11 stoichiometric parameters, the heterotrophic biomass yield $\left(Y_{\mathrm{H}}\right)$ showed high $S_{i, j}$ values for the $\operatorname{TP}\left(S_{i, j}=-2.333\right)$ and $\operatorname{BOD}\left(S_{i, j}=1.481\right)$ concentrations in the effluent (Table 5). This indicated that a small variation in $Y_{\mathrm{H}}$ would result in a

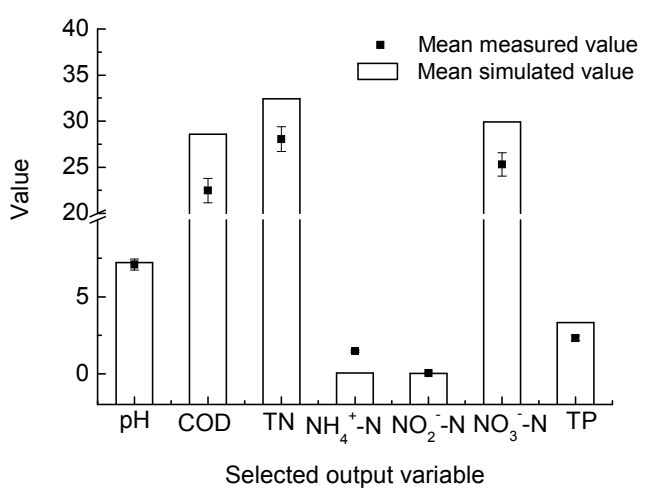

Fig. 4 Measured data vs. simulated values of the selected output variables in the effluent using the default values (unit: $\mathrm{mg} / \mathrm{L}$ except $\mathrm{pH}$ ) large change in the simulated model output on effluent TP and BOD. $Y_{\mathrm{H} \text {,anoxic }}$ exerted an influence $\left(S_{i, j}=\right.$ $-0.467)$ on the effluent TP level, as did the P:COD ratio $\left(S_{i, j}=-0.707\right)$. An increase in the $\mathrm{P}$ concentration in a low COD influent will increase phosphorus levels in the effluent.

The kinetic parameters identified as sensitive were associated with the growth and decay of AOB and OHOs. For the AOB, the maximum growth rate $\left(\mu_{\max }\right)$ influenced most of the simulated model output. Five of the eight simulated model outputs had sensitivity values higher than 2 . The $S_{i, j}$ of $\mu_{\operatorname{maxA}}$ on $\mathrm{NH}_{4}{ }^{+} \mathrm{N}$ was -3.594 , which confirmed that even a slight modification of the value of $\mu_{\max }$ can have a significant impact on the model's output for $\mathrm{NH}_{4}{ }^{+}-\mathrm{N}$. In addition, $K_{\mathrm{NH} 4 \mathrm{~A}}$ was found to have less impact on the nitrification process, i.e., for the AOB the nitrification rate from $\mathrm{NH}_{4}{ }^{+}-\mathrm{N}$ to $\mathrm{NO}_{3}{ }^{-}-\mathrm{N}$ was slower, along with a decreased $\mathrm{K}_{\mathrm{NH} 4 \mathrm{~A}}$. This trend also led to a decrease in TN removal. Similarly, a change in $b_{\text {aeroa,A }}$ can be expected to influence strongly $\mathrm{NH}_{4}{ }^{+}-\mathrm{N}$ under aerobic conditions. For the OHOs, $\mu_{\operatorname{maxH}}, K_{\mathrm{s}}$, and $b_{\mathrm{H}}$ were influential for effluent BOD and TP.

Most of the parameters identified as influential in ASM1 were found to be sensitive in this study for the BioWin AS model. Five out of eight kinetic and stoichiometric parameters belonging to the reduced set of parameters determined in a previous study (Weijers and Vanrolleghem, 1997) were found also to be influential in this work. These parameters were associated with the growth and decay of OHOs and AOB, i.e., $Y_{\mathrm{H}}, \mu_{\operatorname{maxH}}, b_{\mathrm{H}}, \mu_{\operatorname{maxA}}$, and $K_{\mathrm{s}}$. These results

Table $5 S_{i, j}$ values for the most sensitive $\left(S_{i, j} \geq 0.25\right)$ parameters of the calibrated model

\begin{tabular}{|c|c|c|c|c|c|c|c|c|}
\hline \multirow{2}{*}{ Parameter } & \multicolumn{8}{|c|}{$S_{i, j}$} \\
\hline & COD & BOD & $\mathrm{NH}_{4}^{+}-\mathrm{N}$ & $\mathrm{NO}_{3}{ }^{-}-\mathrm{N}$ & $\mathrm{NO}_{2}^{-}-\mathrm{N}$ & $\mathrm{TN}$ & $\mathrm{TP}$ & $\mathrm{pH}$ \\
\hline \multicolumn{9}{|l|}{ Stoichiometric } \\
\hline$Y_{\mathrm{H}}$ & & 1.481 & & & & & -2.333 & \\
\hline$Y_{\mathrm{H} \text {,anoxic }}$ & & & & & & & -0.467 & \\
\hline $\mathrm{P}: \mathrm{COD}$ & & & & & & & -0.707 & \\
\hline \multicolumn{9}{|l|}{ Kinetic } \\
\hline \multicolumn{9}{|l|}{$\mathrm{AOB}$} \\
\hline$\mu_{\operatorname{maxA}}$ & & 1.000 & -3.594 & 2.691 & -3.000 & -3.732 & -2.025 & \\
\hline$K_{\mathrm{NH} 4 \mathrm{~A}}$ & & & 1.155 & & 0.777 & & & \\
\hline$b_{\text {aeroa,A }}$ & & & 3.367 & & 1.175 & 0.558 & 0.264 & \\
\hline \multicolumn{9}{|l|}{ OHOs } \\
\hline$\mu_{\operatorname{maxH}}$ & & -1.852 & & & & & 0.347 & \\
\hline$K_{\mathrm{s}}$ & & 1.046 & & & & & -0.308 & \\
\hline$b_{\mathrm{H}}$ & & 0.886 & & & & & 0.339 & \\
\hline
\end{tabular}


coincide with the findings of Liwarska-Bizukojc and Biernacki (2010) and indicate that some basic parameters of Monod kinetics for $\mathrm{OHOs}$ and $\mathrm{AOB}$ should be determined regardless of the model used, preferably with the help of an appropriate experimental procedure.

\subsection{Model calibration}

Based on the sensitivity analysis, seven parameters ( $b_{\text {aerob, } \mathrm{A}}$ for AOB, $\mu_{\operatorname{maxH}}, b_{\mathrm{H}}, K_{\mathrm{s}}, Y_{\mathrm{H}}, Y_{\mathrm{H} \text {,anoxic }}$ for OHOs and $Y_{\mathrm{PAO}, \text { aerob }}$ for PAOs) were selected to calibrate the specific model in order to match the predicted and measured effluent concentrations. In Table 6, all calibrated parameters for the steady-state and dynamic calibrations are compared with published values (Henze et al., 2000; Liwarska-Bizukojc et al., 2011). Under steady-state conditions, five parameters associated with $\mathrm{AOB}$ and $\mathrm{OHOs}$ needed to be calibrated, while under dynamic conditions, the calibration of all seven parameters associated with three groups of organisms (AOB, OHOs, and PAOs) was necessary. Note that the same parameters that were sensitive in the steady-state calibration were also sensitive in the dynamic calibration. Similar findings were obtained by other researchers (Liwarska-Bizukojc et al., 2011). In the steady-state simulations, there was no need to calibrate the parameters related to PAOs, whereas under dynamic conditions the additional calibration of $Y_{\mathrm{PAO} \text {,aerob }}$ was required to reflect accurately the changes in the phosphorus concentration of the effluent.

The calibration of $Y_{\mathrm{H}}$ and $b_{\mathrm{H}}$ for the heterotrophic biomass was carried out based on the respirometric measurements. The obtained $Y_{\mathrm{H}}$ was $0.72 \mathrm{mg} \mathrm{COD} / \mathrm{mg}$ COD for the activated sludge from the modified AAO plant, which was slightly higher than the default value of $0.67 \mathrm{mg} C O D / \mathrm{mg} C O D$ and very similar to the reported values of 0.71$0.72 \mathrm{mg} \mathrm{COD} / \mathrm{mg}$ COD (Grady et al., 1999). The aerobic decay rate for OHOs $\left(b_{\mathrm{H}}=0.275 \mathrm{~d}^{-1}\right)$ was lower than the default value $\left(0.62 \mathrm{~d}^{-1}\right)$, but remained in the range of the reference values. The calibrated value for the half-saturation constant for the heterotrophic biomass $\left(K_{\mathrm{s}}\right)$ was $2.1 \mathrm{mg} \mathrm{COD} / \mathrm{L}$, which is much lower than either the default value $(5 \mathrm{mg} \mathrm{COD} / \mathrm{L})$ or the published value (4 mg COD/L) (Henze et al., 2000). This relatively low value for $K_{\mathrm{s}}$ was most likely at- tributable to the influent, which consisted of typical municipal wastewater containing heterotrophic biomass with a good affinity for the substrate.

The other four parameters $\left(b_{\text {aerob, } \mathrm{A}}\right.$ for $\mathrm{AOB}, \mu_{\operatorname{maxH}}$, $Y_{\mathrm{H}, \text { anoxic }}$ for $\mathrm{OHOs}$, and $Y_{\mathrm{PAO} \text {,aerob }}$ for PAOs) were calibrated directly through modification of the default values. The observed maximum specific growth rate $\left(\mu_{\operatorname{maxH}}\right)$ was increased from the default value of $3.2 \mathrm{~d}^{-1}$ to $5 \mathrm{~d}^{-1}$, and was still within the range of $\mu_{\operatorname{maxH}}$ in the ASMs. Note that the calibrated optimum decay coefficient $\left(b_{\text {aerob,A } \mathrm{A}}\right)$ for AOB was 4.4 times that of the default value. This may be attributed to the relatively long SRT (16 d) in the BNR system, which influenced the aerobic decay of AOB. In addition, significant fractional differences between the influent in this study and the wastewaters used in other studies accounted reasonably for the discrepancies between the calibrated values and those reported in the literature (Liwarska-Bizukojc et al., 2011).

Based on the $S_{i, j}$ values (Table 5) and the calibrated parameters (Table 6), we conclude that almost all of the calibrated parameters were influential, except $Y_{\mathrm{PAO} \text {,aerob. The sensitivity analysis confirmed that }}$ the model's output was sensitive to those parameters modified from the default values, which warranted the performance of the analysis. Calibration of the $Y_{\mathrm{PAO}, a \mathrm{arob}}$ was necessary to obtain a good prediction of the TP concentration in the effluent.

\subsection{Validation of the calibrated model}

To validate the calibrated model, we determined whether model predictions and measured values from an independent dataset were within acceptable tolerances. A simulation can be considered successful if there are no statistically significant differences between the simulated and measured values of the investigated variables (Petersen et al., 2003). The measured and simulated values after calibration of the selected variables in the effluent under steady-state conditions are shown in Fig. 5. Clearly, each of the simulated output variables is within the confidence interval estimated for the measured effluent $\mathrm{pH}, \mathrm{COD}$, TN, $\mathrm{NH}_{4}{ }^{+}-\mathrm{N}, \mathrm{NO}_{2}{ }^{-}-\mathrm{N}, \mathrm{NO}_{3}{ }^{-}-\mathrm{N}$, and TP. The calibration was therefore successful, which implies that the calibrated model can then be used to predict the general performance of the pilot plant. 
Table 6 Comparison of the default, calibrated, and literature values of the selected parameters

\begin{tabular}{lcccc}
\hline \multicolumn{1}{c}{ Parameter } & $\begin{array}{c}\text { Default } \\
\text { value }\end{array}$ & $\begin{array}{c}\text { Calibrated value } \\
\text { (steady-state) }\end{array}$ & $\begin{array}{c}\text { Calibrated value } \\
\text { (dynamic) }\end{array}$ & $\begin{array}{c}\text { Literature value (Henze } \text { et al., } \\
\text { 2000; Bizukojc } \text { et al., 2011) }\end{array}$ \\
\hline AOB & & & & \\
$\quad b_{\text {aerob,A }}\left(\mathrm{d}^{-1}\right)$ & 0.17 & 0.74 & 0.75 & $0.05-0.15$ \\
\hline OHOs & 3.2 & 6 & 5 & $4-8$ \\
$\mu_{\text {max,H }}\left(\mathrm{d}^{-1}\right)$ & 0.62 & 0.275 & 0.275 & $0.1-0.62$ \\
$b_{\mathrm{H}}\left(\mathrm{d}^{-1}\right)$ & 5 & 2.1 & 2.1 & 4 \\
$K_{\mathrm{s}}(\mathrm{mg} \mathrm{COD} / \mathrm{L})$ & 0.67 & 0.72 & 0.72 & $0.5-0.74$ \\
$Y_{\mathrm{H}}(\mathrm{mg} \mathrm{COD} / \mathrm{mg} \mathrm{COD})$ & 0.54 & - & 0.21 & - \\
$Y_{\mathrm{H}, \text { anoxic }}(\mathrm{mg} \mathrm{COD} / \mathrm{mg} \mathrm{COD})$ & & & 0.50 & $0.5-0.625$ \\
\hline PAOs & & - & 0.64 &
\end{tabular}

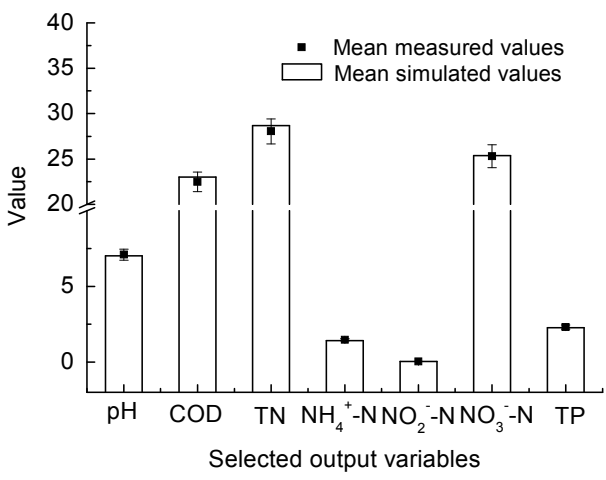

Fig. 5 Measured data vs. simulated values of the selected output variables in the effluent under steady-state conditions (unit: $\mathrm{mg} / \mathrm{L}$ except $\mathrm{pH}$ )

\subsection{Dynamic simulation of the calibrated model}

The calibrated model was used to predict the general performance of the pilot-scale modified AAO plant. Simulated and measured results are presented in Fig. 6. The measured and predicted data for TCOD, $\mathrm{NO}_{3}{ }^{-}-\mathrm{N}, \mathrm{TN}$, and TP in the effluent either overlapped or were within the range of $\pm 20 \%$. This indicates that the calibrated model generally tracked the effluent concentrations of the pilot plant. It should be emphasized that the aim of a dynamic calibration is not to predict each value of an individual output variable, but to predict the trend of its changes. In this respect, the performed dynamic calibration was fully successful.

\section{Conclusions}

In this work, data from a pilot-scale modified AAO plant were used in the calibration and validation of a BioWin AS model. Based on the results obtained, the following conclusions can be summarized:

1. The composition of organic matter by respirometric tests characterized the influent in this study as having relatively lower biodegradable substrates, but higher inert organic matter ratios of TCOD $\left(S_{\mathrm{I}}\right.$, $8.2 \%-22.0 \% ; S_{\mathrm{S}}, 6.0 \%-11.2 \% ; X_{\mathrm{I}}, 60.6 \%-71.1 \% ; X_{\mathrm{S}}$, $6.9 \%-16.8 \%)$. The values determined for two kinetic parameters $Y_{\mathrm{H}}$ and $b_{\mathrm{H}}$ were $0.72 \mathrm{mg} \mathrm{COD} / \mathrm{mg} \mathrm{COD}$ and $0.275 \mathrm{~d}^{-1}$, respectively.

2. Sensitivity analysis is a very useful tool for identifying the most influential parameters and to guide experimental measurements in model calibration. The sensitivity analysis for the parameters of the BioWin AS model revealed that the model's output was most sensitive to the parameters associated with the growth and decay of OHOs and AOB $\left(Y_{\mathrm{H}}, \mu_{\operatorname{maxH}}\right.$, $\left.K_{\mathrm{s}}, b_{\mathrm{H}}, \mu_{\max }, K_{\mathrm{NH} 4 \mathrm{~A}}, b_{\text {aeroa, }}\right)$. Moreover, with the exception of $\mathrm{Y}_{\mathrm{PAO} \text {,aerob}}$, all the calibrated parameters were determined to be influential.

3. Successful calibration was demonstrated by the fact that none of the simulated values exceeded the confidence intervals estimated for the effluent characteristics (pH, $\mathrm{COD}, \mathrm{TN}, \mathrm{NH}_{4}{ }^{+}-\mathrm{N}, \mathrm{NO}_{2}{ }^{-}-\mathrm{N}, \mathrm{NO}_{3}{ }^{-}-\mathrm{N}$, and TP) in the steady-state simulation. In the dynamic simulations, the calibrated model was capable of generally tracking the effluent concentration, predicting the effluent quality (TCOD, $\mathrm{NO}_{3}{ }^{-}-\mathrm{N}, \mathrm{TN}$, and $\mathrm{TP})$ within the range of $0-20 \%$.

4. With the calibrated model, more scenarios can be tested to provide insight into the pilot-scale modified AAO process, as well as information needed to optimize the design and operation when applied at full-scale. 

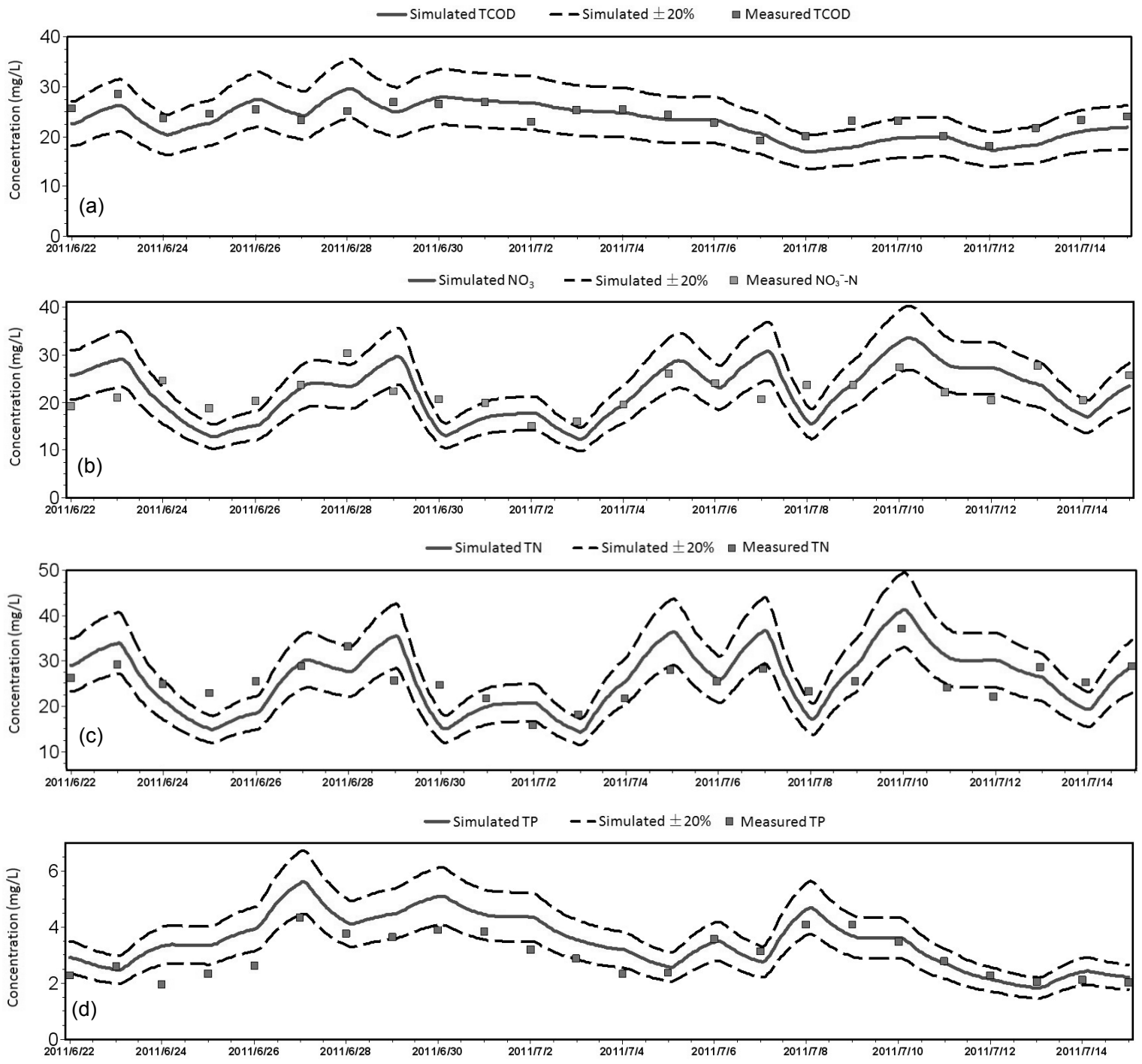

Fig. 6 Dynamic simulation of effluent quality: (a) TCOD; (b) $\mathrm{NO}_{3}{ }^{-}-\mathrm{N}$; (c) TN; (d) TP

\section{References}

APHA, 1998. Standard Methods for the Examination of Water and Wastewater (20th Ed.). Washington DC, USA.

Brun, R., Kuhni, M., Siegrist, H., et al., 2002. Practical identifiability of ASM2d parameters-systematic selection and tuning of parameters subsets. Water Research, 36(16): 4113-4127. [doi:10.1016/S0043-1354(02)00104-5]

Czerwionka, K., Makinia, J., Kaszubowska, M., et al., 2012. Distillery wastes as external carbon sources for denitrification in municipal wastewater treatment plants. $\mathrm{Wa}$ ter Science \& Technology, 65(9):1583-1590. [doi:10. 2166/wst.2012.050]

Fenu, A., Guglielmi, G., Jimenez, J., et al., 2010. Activated sludge model (ASM) based modelling of membrane bioreactor (MBR) processes: A critical review with special regard to MBR specificities. Water Research, 44(15): 4272-4294. [doi:10.1016/j.watres.2010.06.007]

Fu, G., Dong, B., Zhou, Z.Y., et al., 2004. Design characteristics and operating parameters of inverted AAO process. Water
\& Wastewater, 20(9):53-55 (in Chinese).

Gernaey, K.V., van Loosdrecht, M.C.M., Henze, M., et al., 2004. Activated sludge wastewater treatment plant modelling and simulation: state of the art. Environmental Modelling \& Software, 19(9):763-783. [doi:10.1016/j. envsoft.2003.03.005]

Grady, C.P.L.Jr., Daigger, G.T., Lim, H.C., 1999. Biological Wastewater Treatment. Marcel Dekker Inc., New York.

Henze, M., Gujer, W., Mino, T., et al., 2000. Activated sludge models ASM1, ASM2, ASM2d and ASM3. IWA Science and Technical Report No. 9. IWA Publishing, London.

Hu, Z.R., Houweling, D., Dold, P., 2012. Biological nutrient removal in municipal wastewater treatment: new directions in sustainability. Journal of Environmental Engineering, 138(3):307-317. [doi:10.1061/(ASCE)EE.19437870.0000462]

Langergraber, G., Rieger, L., Winkler, S., et al., 2004. A guideline for simulation studies of wastewater treatment 
plants. Water Science \& Technology, 50(7):131-138.

Liwarska-Bizukojc, E., Biernacki, R., 2010. Identification of the most sensitive parameters in the activated sludge model implemented in BioWin software. Bioresource Technology, 101(19):7278-7285. [doi:10.1016/j.biortech. 2010.04.065]

Liwarska-Bizukojc, E., Olejnik, D., Biernacki, R., et al., 2011. Calibration of a complex activated sludge model for the full-scale wastewater treatment plant. Bioprocess and Biosystems Engineering, 34(6):659-670. [doi:10.1007/ s00449-011-0515-1]

Makinia, J., Rosenwinkel, K.H., Swinarski, M., et al., 2006. Experimental and model-based evaluation of the role of denitrifying polyphosphate accumulating organisms at two large scale WWTPs in northern Poland. Water Science \& Technology, 54(8):73-81. [doi:10.2166/wst.2006. 711]

Ni, B.J., Yu, H.Q., 2008. Simulation of heterotrophic storage and growth processes in activated sludge under aerobic conditions. Chemical Engineering Journal, 140(1-3): 101-109. [doi:10.1016/j.cej.2007.09.017]

Ni, B.J., Xie, W.M., Liu, S.G., et al., 2009. Modeling and simulation of the sequencing batch reactor at a full-scale municipal wastewater treatment plant. AIChE Journal, 55(8):2186-2196. [doi:10.1002/aic.11820]

Pai, T.Y., 2007. Modeling nitrite and nitrate variations in $\mathrm{A}^{2} \mathrm{O}$ process under different return oxic mixed liquid using an extended model. Process Biochemistry, 42(6):978-987. [doi:10.1016/j.procbio.2007.03.006]

Petersen, B., Gernaey, K., Henze, M., et al., 2002. Evaluation of an ASM1 model calibration procedure on a municipalindustrial wastewater treatment plant. Journal of $\mathrm{Hy}$ droinform, 4(1): 15-38.

Petersen, B., Gernaey, K., Henze, M., et al., 2003. Calibration of activated sludge models: a critical review of experimental designs. Biotechnology for the Environment: Wastewater Treatment and Modelling, Waste Gas Handling. Kluwer Academic Publishers, Dordrecht.

Sin, G., van Hulle, S.W.H., de Pauw, D.J.W., et al., 2005. A critical comparison of systematic calibration protocols for activated sludge models: a SWOT analysis. Water Research, 39(12):2459-2474. [doi:10.1016/j.watres.2005.05. 006]

US EPA, 2009. Guidance on the Development, Evaluation and Application on Environmental Models, EPA 100/K-09003. Washington DC, USA.

Vanrolleghem, P.A., Insel, G., Petersen, B., et al., 2003. A comprehensive model calibration procedure for activated sludge models. Proceedings of the Water Environment Federation, 76th Annual Technical Exhibition and Conference, Los Angeles, CA, USA, p.210-237. [doi:10. 2175/193864703784639615]

Weijers, S.R., Vanrolleghem, P.A., 1997. A procedure for selecting best identifiable parameters in calibrating activated sludge model No. 1 to full-scale plant data. Water Science \& Technology, 36(5):69-79. [doi:10.1016/S02731223(97)00463-0]

Zhang, B., Gao, T.Y., 2000. Principle and characteristics of reversed A2/O process. Water \& Wastewater, 16(7):11-15 (in Chinese).

Zhou, Z., Wu, Z.C., Wang, Z.W., et al., 2009. Fractionation of soluble COD in wastewater based on batch respirometric method. Environmental Science, 30(1):75-79 (in Chinese).

Zhou, Z., Wu, Z.C., Wang, Z.W., et al., 2011. Simulation and performance evaluation of the anoxic/anaerobic/aerobic process for biological nutrient removal. Korean Journal of Chemical Engineering, 28(5):1233-1240. [doi:10. 1007/s11814-010-0502-2]

\section{中文䇾要:}

\section{本文题目：基于缺氧/厌氧/好氧/后缺氧工艺的活性污泥模型的校正及验证}

Calibration and validation of an activated sludge model for a pilot-scale anoxic/anaerobic/ aerobic/post-anoxic process

研究目的: 以中试规模的缺氧/厌氧/好氧/后缺氧污水处理工艺为研究对象, 利用 $\mathrm{BioWin}^{\mathrm{TM}}$ 软件平台及 其内嵌的通用活性污泥数学模型，建立该工艺的模拟模型并进行校正及验证，为优化该工艺 的设计及运行提供指导。

创新要点: 成功建立了缺氧/厌氧/好氧/后缺氧工艺的活性污泥数学模型, 甄别出对模型输出有显著影响 的灵敏性参数。

研究方法: 通过呼吸试验获取进水水质特征, 利用 $\mathrm{BioWin}^{\mathrm{TM}}$ 软件平台及其内嵌的通用活性污泥数学模 型，建立该工艺的模拟模型，利用模型缺省值进行初步稳态模拟，借助灵敏度分析方法篎选 出重要的化学计量学参数及动力学参数并进行模型校正, 利用校正后的模型对该工艺进行了 动态模拟。

重要结论: 灵敏度分析可优化模型的校正过程, 该工艺出水水质对异养菌 (OHOs) 和氨氧化菌 (AOB) $\left(Y_{\mathrm{H}} 、 \mu_{\operatorname{maxH}} 、 K_{\mathrm{s}} 、 b_{\mathrm{H}} 、 \mu_{\operatorname{maxA}} 、 K_{\mathrm{NH} 4 \mathrm{~A}}\right.$ 和 $\left.b_{\text {aeroa, } \mathrm{A}}\right)$ 的灵敏度较高。校正后的模型稳态模拟出水 水质 $\left(\mathrm{pH} 、 \mathrm{COD} 、 \mathrm{TN} 、 \mathrm{NH}_{4}{ }^{+}-\mathrm{N} 、 \mathrm{NO}_{2}{ }^{-}-\mathrm{N} 、 \mathrm{NO}_{3}{ }^{-}-\mathrm{N}\right.$ 和 $\left.\mathrm{TP}\right)$ 控制在与实测出水相应的 $95 \%$ 置信区间内（图 5), 表明稳态模型建模成功, 在此基础上运行的动态模拟准确地反映了工 艺实际运行中的浓度变化趋势（图 6), 具有良好的模拟效果。

关键词组: 活性污泥模型; 模拟; 校正; 验证; 灵敏度分析 